\title{
Association between serum sST2 levels and CD4+T cells in patients with organ failure: a pilot study
}

\author{
qisong Peng ${ }^{1}$, guoyou $\mathrm{Shi}^{1}$, and hongxiang $\mathrm{lu}^{1}$ \\ ${ }^{1}$ The Affiliated Jiangning Hospital of Nanjing Medical University
}

July 28, 2021

\begin{abstract}
Background: The importance of sST2 has been increasingly appreciated because of its associated with the development of heart failure and related diseases. Objective: The aim of this study was to evaluate the association of sST2 with CD4+T cells in patients with organ failure. Methods: $100(\mathrm{M}: \mathrm{F}=60: 40)$ organ failure patients aged (mean $\pm \mathrm{SD}=69.08 \pm 16.68)$ and 30 $(\mathrm{M}: \mathrm{F}=14: 16)$ normal control aged (mean $\pm \mathrm{SD}=60.23 \pm 13.99)$ serum $\mathrm{sST} 2$ were detected by chemiluminescence assay (CLIA) and the expression of serum IL-1, IL-6 and TNF- $\alpha$ were analyzed by enzyme-linked immunosorbent assay (ELISA). The proportion of $\mathrm{CD} 4+\mathrm{T}$ cells in peripheral blood was determined by flow cytometry (FCM). Association of sST2 with CD4+T cells in organ failure patents were analyzed by SPASS. Results: The expression of sST2 in organ failure patients $(107.4 \pm 5.79 \mathrm{ng} / \mathrm{mL})$ was significantly higher than normal control $(8.57 \pm 0.35 \mathrm{ng} / \mathrm{mL})$. Inflammatory factors IL-1 and IL-6 in patients were also increased than normal controls (IL-1: $0.33 \pm 0.04 \mathrm{pg} / \mathrm{mL}$ vs $0.14 \pm 0.02 \mathrm{pg} / \mathrm{mL}$. IL-6: $165.7 \pm 10.53 \mathrm{pg} / \mathrm{mL}$ vs $95.33 \pm 7.42 \mathrm{pg} / \mathrm{mL}$. TNF- $\alpha: 1.57 \pm 0.14 \mathrm{pg} / \mathrm{mL}$ vs $6.11 \pm 0.77 \mathrm{pg} / \mathrm{mL})$. In patients, the results showed CD4+T cells were reduced compare with normal control $(238.3 \pm 13.67 / \mu \mathrm{L}$ vs $1081 \pm 39.13 / \mu \mathrm{L})$. Additionally, sST2 was found to be inversely associated with CD4+T cell in patients with organ failure. Conclusion: sST2 level was closely related to the development of organ failure and sST2 was obviously correlated with CD4+T cell in patients with organ failure.
\end{abstract}

\section{Association between serum sST2 levels andCD4 ${ }^{+} \mathrm{T}$ cells in patients with organ failure: a pilot study}

Qisong Peng ${ }^{1+}$, Guoyou Shi ${ }^{1+}$, Hongxiang $\mathrm{Lu}^{1 *}$

${ }^{1}$ The Affiliated Jiangning Hospital with Nanjing Medical University, Nanjing 211100, China

+ These two authors contributed equally to this work.

*Correspondence: Hongxiang Lu, Jiangning Hospital with Nanjing Medical University, 169 Hushan Road, Nanjing, Jiangsu 211100, China, Email: hero_0620@163.com

Running title:Association of sST2 with $\mathrm{CD} 4^{+} \mathrm{T}$ cells in organ failure

\section{Abstract}

Background: The importance of sST2 has been increasingly appreciated because of its associated with the development of heart failure and related diseases.

Objective: The aim of this study was to evaluate the association of sST2 with $\mathrm{CD} 4^{+} \mathrm{T}$ cells in patients with organ failure.

Methods: 100 (M:F=60:40) organ failure patients aged (mean $\pm \mathrm{SD}=69.08 \pm 16.68)$ and $30(\mathrm{M}: \mathrm{F}=14: 16)$ normal control aged (mean $\pm \mathrm{SD}=60.23 \pm 13.99)$ serum $\mathrm{sST} 2$ were detected by chemiluminescence assay (CLIA) and the expression of serum IL-1, IL- 6 and TNF- $\alpha$ were analyzed by enzyme-linked immunosorbent assay 
(ELISA). The proportion of CD4 ${ }^{+} \mathrm{T}$ cells in peripheral blood was determined by flow cytometry (FCM). Association of sST2 with $\mathrm{CD} 4^{+} \mathrm{T}$ cells in organ failure patents were analyzed by SPASS.

Results: The expression of sST2 in organ failure patients $(107.4 \pm 5.79 \mathrm{ng} / \mathrm{mL})$ was significantly higher than normal control $(8.57 \pm 0.35 \mathrm{ng} / \mathrm{mL})$. Inflammatory factors IL-1 and IL-6 in patients were also increased than normal controls (IL-1: $0.33 \pm 0.04 \mathrm{pg} / \mathrm{mL}$ vs $0.14 \pm 0.02 \mathrm{pg} / \mathrm{mL}$. IL- $6: 165.7 \pm 10.53 \mathrm{pg} / \mathrm{mL}$ vs $95.33 \pm 7.42 \mathrm{pg} / \mathrm{mL}$. TNF- $\alpha: \quad 1.57 \pm 0.14 \mathrm{pg} / \mathrm{mL}$ vs $6.11 \pm 0.77 \mathrm{pg} / \mathrm{mL}$ ). In patients, the results showed CD4 ${ }^{+} \mathrm{T}$ cells were reduced compare with normal control $(238.3 \pm 13.67 / \mu \mathrm{L}$ vs $1081 \pm 39.13 / \mu \mathrm{L})$. Additionally, sST2 was found to be inversely associated with $\mathrm{CD} 4^{+} \mathrm{T}$ cell in patients with organ failure.

Conclusion: sST2 level was closely related to the development of organ failure and sST2 was obviously correlated with $\mathrm{CD} 4^{+} \mathrm{T}$ cell in patients with organ failure.

Key words: $\mathrm{sST} 2, \mathrm{CD} 4^{+} \mathrm{T}$ cell, organ failure

\section{What's already known about this topic?}

The serum sST2 levels are found to independently predict all-cause mortality and heart failure hospitalization in patients with chronic heart failure.

\section{What's does this article add?}

The present study suggests that sST2 not only involved in the occurrence of heart failure, but also plays an important role in development of multiple organ failure. Both sST2 and $\mathrm{CD}^{+} \mathrm{T}$ cells are involved in the progression of this disease.

\section{Introduction}

Organ failure (OF), as a general term, can be defined as impairment of vital functions of organ systems that are essential to the maintenance of life ${ }^{1}$. The common causes are as follows: Severe trauma, Severe infection, Major surgical operations, Various types of shock, Cardiac arrest ${ }^{2}$. The severity of organ dysfunction can be quantified according to the parameters that best define the major functions of a particular organ, such as partial pressure of arterial oxygen $\left(\mathrm{PaO}_{2}\right)$ for pulmonary function or serum creatinine for renal function. Published data have showed that the serum sST2 levels were considered as independently predict all-cause mortality in patients with chronic heart failure ${ }^{3}$. However, the role of sST2 in OF patients remains unclear.

Suppression of tumorigensis-2 (ST2) is a member of the interleukin (IL)-1 receptor family ${ }^{4,5}$, with four protein isoforms identified to date. The two main isoforms are a transmembrane receptor ST2L and a soluble ST2 isoform (sST2) $)^{6,7}$. IL-33 binds to ST2L and activates mitogen-activated protein kinases (MAPK) and several biochemical pathways ${ }^{8,9}$. However, sST2 avidly binds IL-33, which results in interruption of the interaction between IL-33/ST2L; thus, sST2 is viewed as a decoy receptor, preventing transduction of favorable effects of IL-33 through ST2L ${ }^{10}$. Serum sST2 has been used as a biomarker for predicting heart failure, whether ST2 can be used as a screening indicator for other OF, or whether it can be combined with other related indicators to screen for OF.

$\mathrm{CD} 4^{+} \mathrm{T}$ cells play a vital role in the adaptive immune response and are involved in the pathogenesis of many diseases ${ }^{11}$, including autoimmune diseases ${ }^{12}$, cancer ${ }^{13}$, and chronic inflammation ${ }^{14}$. As a major arm of the cellular immune response, CD4 ${ }^{+} \mathrm{T}$ cells can be classified as Th1 (T-bet and IFN- $\gamma$ ), Th2 (GATA3 and IL-4/IL-13), Th17 (ROR- $\gamma$ t and IL-17), Tfh (Bcl6 and IL-21) and Treg (Foxp3 and IL-10/IL-35) according to the expression of characteristic cytokines and their lineage-specific transcription factors ${ }^{15,16}$. As a highly heterogeneous population of cells, it is not clear whether they are involved in the development of OF.

Therefore, the present work was to address the above question; our results showed that serum sST2 levels were significantly up-regulated in OF patients and peripheral blood $\mathrm{CD} 4^{+} \mathrm{T}$ cells significantly decreased with the increase of sST2. The present work revealed a novel role and phenomenon of sST2: Serum sST2 level was obviously correlated with the number of $\mathrm{CD} 4^{+} \mathrm{T}$ cells in $\mathrm{OF}$ patients.

\section{Materials and Methods}




\section{Study population}

100 patients with organ failure in Jiangning Hospital of Nanjing Medical University from September 2020 to March 2021 were randomly selected, including 60 males and 40 females, with an average age of $69.08 \pm 16.68$ years. In addition, 30 healthy subjects (blood routine, urine routine, liver and kidney function, heart color ultrasound, blood glucose and other examinations were normal) were selected as the normal control group, including 14 males and 16 females, with an average age of $60.23 \pm 13.99$ years old. This study was approved by the Ethics Committee of Jiangning Hospital Affiliated to Nanjing Medical University.

\section{Data collection}

Serological indicators for normal controls and for patients with organ failure were obtained from the Nanjing Jiangning Hospital record system.

\section{ELISA}

Peripheral blood samples were centrifuged at $1500 \mathrm{r} / \mathrm{min}$ for $5 \mathrm{~min}$, serum was collected and stored at $-80^{\circ} \mathrm{C}$ until use. IL-6, IL-1 were measured by ELISA kits according to the manufacturer's instructions.

\section{Flow cytometry}

Peripheral blood samples were collected and $100 \mu \mathrm{l}$ was absorbed and added into flow tube. Then 10ul CD45/CD4/CD8/CD3 flow antibody was added. After swirl shock, the cells were incubated for 15-20min in dark at room temperature. After incubation, add 500 $\mu$ l Optilyse-C, mix with swirl vibration, and incubate

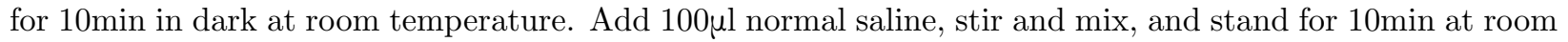
temperature in the dark. Then, mix Flow-Count vortex oscillation for 10s, take 100 $\mu$ l of the mixture and the data were analysed using FlowJo software.

\section{Chemiluminescence assay (CLIA)}

Peripheral blood samples were centrifuged at $3000 \mathrm{r} / \mathrm{min}$ for $15 \mathrm{~min}$, and $50 \mu \mathrm{l}$ of serum samples were taken and added into the test buffer tube, and thoroughly mixed. Then absorb $100 \mu l$ of the mixture and add it vertically to the sample well of the reaction plate. After reaction for 10min, the instrument was used for rapid detection.

\section{Statistical analysis}

All statistical analyses were performed using SPSS and GraphPad Prism 5 software. Data are expressed as the mean \pm standard deviation (SD). Comparisons between groups were performed using paired t-test or one-way ANOVA with Bonferroni correction. $P$ values less than 0.05 were considered statistically significant.

\section{Results}

Table 1 depicts a comparison of serological indicators in OF patients versus NC In heart failure patients, 60 patients comprising 35 men and 25 women $(\mathrm{M}: \mathrm{F}=1.4: 1)$ aged (mean $\pm \mathrm{SD}=65.06 \pm 12.32$ years) the serological indicator CK-MB $(20.53 \pm 10.45 \mu \mathrm{g} / \mathrm{L}$ vs $0.96 \pm 0.11 \mu \mathrm{g} / \mathrm{L}, \mathrm{P}<0.05), \mathrm{MYO}(924.4 \pm 201.3 \mu \mathrm{g} / \mathrm{L}$ vs $42.41 \pm 4.94 \mu \mathrm{g} / \mathrm{L}, \quad \mathrm{P}<0.001), \quad$ cTNI $\quad(1.123 \pm 0.35 \mu \mathrm{g} / \mathrm{L} \quad$ vs $0.023 \pm 0.011 \mu \mathrm{g} / \mathrm{L}, \quad \mathrm{P}<0.05)$ and $\mathrm{BNP}$ $(2753 \pm 576.1 \mathrm{ng} / \mathrm{L}$ vs $0.96 \pm 0.11 \mathrm{ng} / \mathrm{L}, \mathrm{P}<0.001)$ were higher than $30 \mathrm{NC}$ comprising 14 men and 16 women $(\mathrm{M}: \mathrm{F}=7: 8)$ aged (mean $\pm \mathrm{SD}=60.23 \pm 13.99$ years). In renal failure patients, 40 patients comprising 27 men and 13 women $(\mathrm{M}: \mathrm{F}=2.08: 1)$ aged (mean $\pm \mathrm{SD}=61.22 \pm 9.38$ years) the serological indicator $\mathrm{BUN}$ $(21.06 \pm 2.13 \mathrm{mmol} / \mathrm{L}$ vs $5.58 \pm 0.33 \mathrm{mmol} / \mathrm{L}, \mathrm{P}<0.001)$, Cr $(21.06 \pm 2.13 \mu \mathrm{mol} / \mathrm{L}$ vs $5.58 \pm 0.33 \mu \mathrm{mol} / \mathrm{L}, \mathrm{P}<0.01)$, CysC $(282.5 \pm 56.56 \mathrm{mg} / \mathrm{L}$ vs $72.62 \pm 5.73 \mathrm{mg} / \mathrm{L}, \quad \mathrm{P}<0.01), \quad \beta 2-\mathrm{MG} \quad(9.74 \pm 1.48 \mathrm{mg} / \mathrm{L}$ vs $1.94 \pm 0.18 \mathrm{mg} / \mathrm{L}$, $\mathrm{P}<0.001)$ were also significantly higher than $30 \mathrm{NC}$ comprising 14 men and 16 women $(\mathrm{M}: \mathrm{F}=7: 8)$ aged (mean $\pm \mathrm{SD}=60.23 \pm 13.99$ years), respectively.

The OF patients

The expression of serum inflammatory mediators were up-regulated in OF patients 
The occurrence of the vast majority of diseases is caused by inflammation, so we carried out the detection of inflammatory mediators in the serum of OF patients, and the results showed that compare with $\mathrm{NC}$, the OF patients have a higher expression of inflammatory mediators IL- $1(0.3638 \pm 0.01917 \mathrm{pg} / \mathrm{mL}$ vs $0.131 \pm 0.011 \mathrm{pg} / \mathrm{mL}, \mathrm{P}<0.001)$, IL-6 $(133.7 \pm 10.94 \mathrm{pg} / \mathrm{mL}$ vs $79.59 \pm 8.775 \mathrm{pg} / \mathrm{mL}, \mathrm{P}<0.001)$ and $\mathrm{TNF}-\alpha$ $(1.57 \pm 0.14 \mathrm{pg} / \mathrm{mL}$ vs $6.11 \pm 0.77 \mathrm{pg} / \mathrm{mL}$ ) (Figure 1$)$.

\section{sST2 as a screening index for OF patients}

Published data show that sST2 was found to independently predict all-cause mortality and heart failure hospitalization in patients with chronic heart failure. In this study, we also found in OF patients the serum expression of sST2 was obviously higher than $\mathrm{NC}(107.4 \pm 5.791 \mathrm{ng} / \mathrm{mL}$ vs $8.567 \pm 0.3466 \mathrm{ng} / \mathrm{mL}, \mathrm{P}<0.001)$ (Figure 2). It means that sST2 can be used as an key screening index for OF patients.

\section{$\mathrm{CD}^{+} \mathrm{T}$ cells were decreased in $\mathrm{OF}$ patients}

$\mathrm{CD} 4^{+} \mathrm{T}$ cells play an important role in tumors, autoimmune diseases, and inflammatory diseases. whether $\mathrm{CD} 4^{+} \mathrm{T}$ cells also involved in the progressing of OF patients. The data showed a reduction in the number of $\mathrm{CD}^{+} \mathrm{T}$ cells in OF patients compared with $\mathrm{NC}(238.3 \pm 13.67 / \mu \mathrm{L}$ vs $1081 \pm 39.13 / \mu \mathrm{L}, \mathrm{P}<0.001)$ (Figure 3 ). It suggests that $\mathrm{CD} 4^{+} \mathrm{T}$ cells are involved in $\mathrm{OF}$ patients.

\section{sST2 was obviously correlated with $\mathrm{CD}^{+} \mathrm{T}$ cell in OF patients}

Above results suggested that both ST2 and $\mathrm{CD} 4^{+} \mathrm{T}$ cells cells are involved in the pathogenesis of OF patients. Whether there is a correlation between them in OF patients. As Table2 showed an obviously correlation between sST2 and $\mathrm{CD} 4^{+} \mathrm{T}$ cells in OF patients. It may also be an important reference index to evaluate the progress of OF patients.

\section{Discussion}

Organ failure, or multiple organ failure, is an important reason for the death of elderly people, mostly those over 70 years old. Organ failure includes chronic diseases of important body organs such as trachea, heart, kidney, and brain ${ }^{17}$. Complications include shortness of breath, rapid drop in blood pressure, hypoxia of lips and nails, unresponsiveness of the optic nerve, hazy consciousness, hypoxia of blood, shock, coma, etc ${ }^{18,19}$. sST2 protein belongs to the interleukin 1 receptor family and can be produced by cardiomyocytes and cardiac fibroblasts when they are subjected to mechanical tension ${ }^{4}$. sST2 antagonizes the activation of IL-33 pathway and promotes the occurrence of cardiomyocyte hypertrophy and myocardial fibrosis ${ }^{20}$, and is increasingly regarded as a new marker for the diagnosis of heart failure. With the deepening of research, published data have shown that sST2 was involved in airway inflammation ${ }^{21}$, pulmonary hypertension ${ }^{22}$, schizophrenia ${ }^{23}$ and other diseases. As a plasticity population, $\mathrm{CD} 4^{+} \mathrm{T}$ cells play an important role in the process of tissue damage and repair. For example, in the inflammatory environment, CD4 $4^{+} \mathrm{T}$ cells differentiate into Th17 and then participate in myocardial inflammatory injury ${ }^{24}$, kidney ${ }^{25}$ and liver fibrosis ${ }^{26}$, etc. Therefore, the origin of sST2 and whether it is involved in the regulation of $\mathrm{CD}^{+} \mathrm{T}$ cells differentiation and thus in OF are the focus of research.

The present results demonstrate that the expression of the inflammatory mediator IL-1, IL-6 and TNF- $\alpha$ were increased in peripheral blood serum of OF patients caused by inflammatory injury and the serum sST2 levels were also significantly up-regulated compare with NC. It suggests that sST2 can be used as a screening index for OF. At the same time, we also found that the number of $\mathrm{CD} 4^{+} \mathrm{T}$ cells in peripheral blood decreased in patients with increased sST2. Additionally, some data show that IL-33/ST2 axis could regulate the proliferation of regulatory $\mathrm{T}$ cells $(\mathrm{Treg})^{27}$, whether it suggests that sST2 may regulate $\mathrm{CD} 4^{+} \mathrm{T}$ cells function and participate in OF remains to be confirmed.

In conclusion, the regulation of sST2 on OF is partly dependent on $\mathrm{CD} 4^{+} \mathrm{T}$ cells, and sST2 is an important screening indicator for the diagnosis of organ failure.

\section{Acknowledgments}


We would like to acknowledge the support and services of the Jiangning Hospital of Nanjing Medical University staff during the conduct of the study.

\section{Author contribution:}

Qisong Peng: Design, Data Analysis, Writing the manuscript.

Guoyou Shi: Biochemical Analysis, Reviewing the manuscript.

Hongxiang Lu: Conducting the study, Data Collection, Reviewing the manuscript.

\section{Research funding}

This work was supported by a grant from Clinical Medical Science and Technology Development Foundation of Jiangsu University (Grant No.JLY2021154) and the Jiangning Hospital with Nanjing Medical University Talents Program (Grant No. JNYYRC202005).

\section{Conflict of Interests}

There is no conflict of interest statement.

\section{Reference}

1. Garg PK, Singh VP. Organ Failure Due to Systemic Injury in Acute Pancreatitis. Gastroenterology. 2019;156(7):2008-2023.

2. Dinca VG, Manole G. Organ failure as an expression of organ remodeling. Involvement of oxidative stress. J Med Life.2013;6(3):240-243.

3. Emdin M, Aimo A, Vergaro G, et al. sST2 Predicts Outcome in Chronic Heart Failure Beyond NTproBNP and High-Sensitivity Troponin T. J Am Coll Cardiol. 2018;72(19):2309-2320.

4. Matilla L, Ibarrola J, Arrieta V, et al. Soluble ST2 promotes oxidative stress and inflammation in cardiac fibroblasts: an in vitro and in vivo study in aortic stenosis. Clin Sci (Lond).2019;133(14):1537-1548.

5. Villacorta H, Maisel AS. Soluble ST2 Testing: A Promising Biomarker in the Management of Heart Failure. Arq Bras Cardiol.2016;106(2):145-152.

6. Rehman SU, Mueller T, Januzzi JL, Jr. Characteristics of the novel interleukin family biomarker ST2 in patients with acute heart failure.J Am Coll Cardiol. 2008;52(18):1458-1465.

7. Pascual-Figal DA, Januzzi JL. The biology of ST2: the International ST2 Consensus Panel. Am J Cardiol. 2015;115(7 Suppl):3B-7B.

8. Kakkar R, Lee RT. The IL-33/ST2 pathway: therapeutic target and novel biomarker. Nat Rev Drug Discov. 2008;7(10):827-840.

9. Sanada S, Hakuno D, Higgins LJ, Schreiter ER, McKenzie AN, Lee RT. IL-33 and ST2 comprise a critical biomechanically induced and cardioprotective signaling system. J Clin Invest.2007;117(6):1538-1549.

10. Asensio-Lopez MC, Lax A, Fernandez Del Palacio MJ, et al. Yin-Yang 1 transcription factor modulates ST2 expression during adverse cardiac remodeling post-myocardial infarction. J Mol Cell Cardiol.2019;130:216-233.

11. Zhu X, Zhu J. CD4 T Helper Cell Subsets and Related Human Immunological Disorders. Int J Mol Sci. $2020 ; 21(21)$.

12. Vdovenko D, Eriksson U. Regulatory Role of CD4(+) T Cells in Myocarditis. J Immunol Res. 2018;2018:4396351.

13. Cachot A, Bilous M, Liu YC, et al. Tumor-specific cytolytic CD4 T cells mediate immunity against human cancer. Sci Adv. 2021;7(9). 
14. Pucino V, Certo M, Bulusu V, et al. Lactate Buildup at the Site of Chronic Inflammation Promotes Disease by Inducing CD4(+) T Cell Metabolic Rewiring. Cell Metab. 2019;30(6):1055-1074 e1058.

15. Chatzileontiadou DSM, Sloane H, Nguyen AT, Gras S, Grant EJ. The Many Faces of CD4(+) T Cells: Immunological and Structural Characteristics. Int J Mol Sci. 2020;22(1).

16. Zhu J, Yamane H, Paul WE. Differentiation of effector CD4 T cell populations $\left({ }^{*}\right)$. Annu Rev Immunol. 2010;28:445-489.

17. Moreau R, Arroyo V. Acute-on-chronic liver failure: a new clinical entity. Clin Gastroenterol Hepatol. $2015 ; 13(5): 836-841$.

18. Mannes M, Schmidt CQ, Nilsson B, Ekdahl KN, Huber-Lang M. Complement as driver of systemic inflammation and organ failure in trauma, burn, and sepsis. Semin Immunopathol. 2021.

19. Linkermann A, Stockwell BR, Krautwald S, Anders HJ. Regulated cell death and inflammation: an auto-amplification loop causes organ failure. Nat Rev Immunol. 2014;14(11):759-767.

20. Matilla L, Arrieta V, Jover E, et al. Soluble St2 Induces Cardiac Fibroblast Activation and Collagen Synthesis via Neuropilin-1.Cells. 2020;9(7).

21. Ma Q, Qian Y, Jiang J, et al. IL-33/ST2 axis deficiency exacerbates neutrophil-dominant allergic airway inflammation. Clin Transl Immunology. 2021;10(6):e1300.

22. Vu LD, Saravia J, Jaligama S, et al. Deficiency of ST2 signaling ameliorates RSV-associated pulmonary hypertension. Am J Physiol Heart Circ Physiol. 2021.

23. Borovcanin MM, Minic Janicijevic S, Jovanovic IP, Gajovic NM, Jurisevic MM, Arsenijevic NN. Type 17 Immune Response Facilitates Progression of Inflammation and Correlates with Cognition in Stable Schizophrenia. Diagnostics (Basel). 2020;10(11).

24. Chen R, Cao Y, Tian Y, et al. PGE2 ameliorated viral myocarditis development and promoted IL-10-producing regulatory B cell expansion via MAPKs/AKT-AP1 axis or AhR signaling. Cell Immunol.2020;347:104025.

25. Lee SA, Noel S, Kurzhagen JT, et al. CD4(+) T Cell-Derived NGAL Modifies the Outcome of Ischemic Acute Kidney Injury. J Immunol.2020;204(3):586-595.

26. Cheng LS, Liu Y, Jiang W. Restoring homeostasis of CD4(+) T cells in hepatitis-B-virus-related liver fibrosis. World J Gastroenterol.2015;21(38):10721-10731.

27. Xu L, Li W, Wang X, et al. The IL-33-ST2-MyD88 axis promotes regulatory $\mathrm{T}$ cell proliferation in the murine liver. Eur J Immunol. 2018;48(8):1302-1307.

Table 1: Baseline characteristics of OF patients

Values are expressed as mean $\pm \mathrm{SD}$. HF: heart failure; NC: normal control; RF: renal failure;CK-MB: creatine kinase-MB; MYO: myoglobin; cTNI: cardiac troponin I; BNP: type B natriuretic peptide; BUN: blood urea nitrogen; Cr: creatinine; CysC: cystatin C; $\beta 2$-MG: beta 2-microglobulin. Differences were considered statistically significant if $\mathrm{P}<0.05 .{ }^{*} \mathrm{P}<0.05,{ }^{* *} \mathrm{P}<0.01,{ }^{* * *} \mathrm{P}<0.001$.

\section{Table 2: Association of sST2 with $\mathrm{CD}^{+}{ }^{+} \mathrm{T}$ cells in $\mathrm{OF}$ patients}

\section{Figure legends}

Figure 1 Inflammatory cytokines were up-regulated in patients of OF. The clinical serum samples were collected and IL-1, IL- 6 and TNF- $\alpha$ were quantitated by ELISA . Data are presented as means \pm SD. ${ }^{*} \mathrm{P}<0.05,{ }^{* *} \mathrm{P}<0.01$

Figure 2 Serum sST2 levels were up-regulated in patients of OF. The clinical serum samples were collected and sST2 was analyzed by CLIA. Data are presented as means $\pm \mathrm{SD}$. ${ }^{* * *} \mathrm{P}<0.001$. 
Figure $3 \mathrm{CD}^{+} \mathrm{T}$ cells were decreased in patients of OF. The clinical peripheral blood samples were collected and the counts of $\mathrm{CD} 4^{+} \mathrm{T}$ cells were analyzed by $\mathrm{FCM} .{ }^{* * *} \mathrm{P}<0.001$.
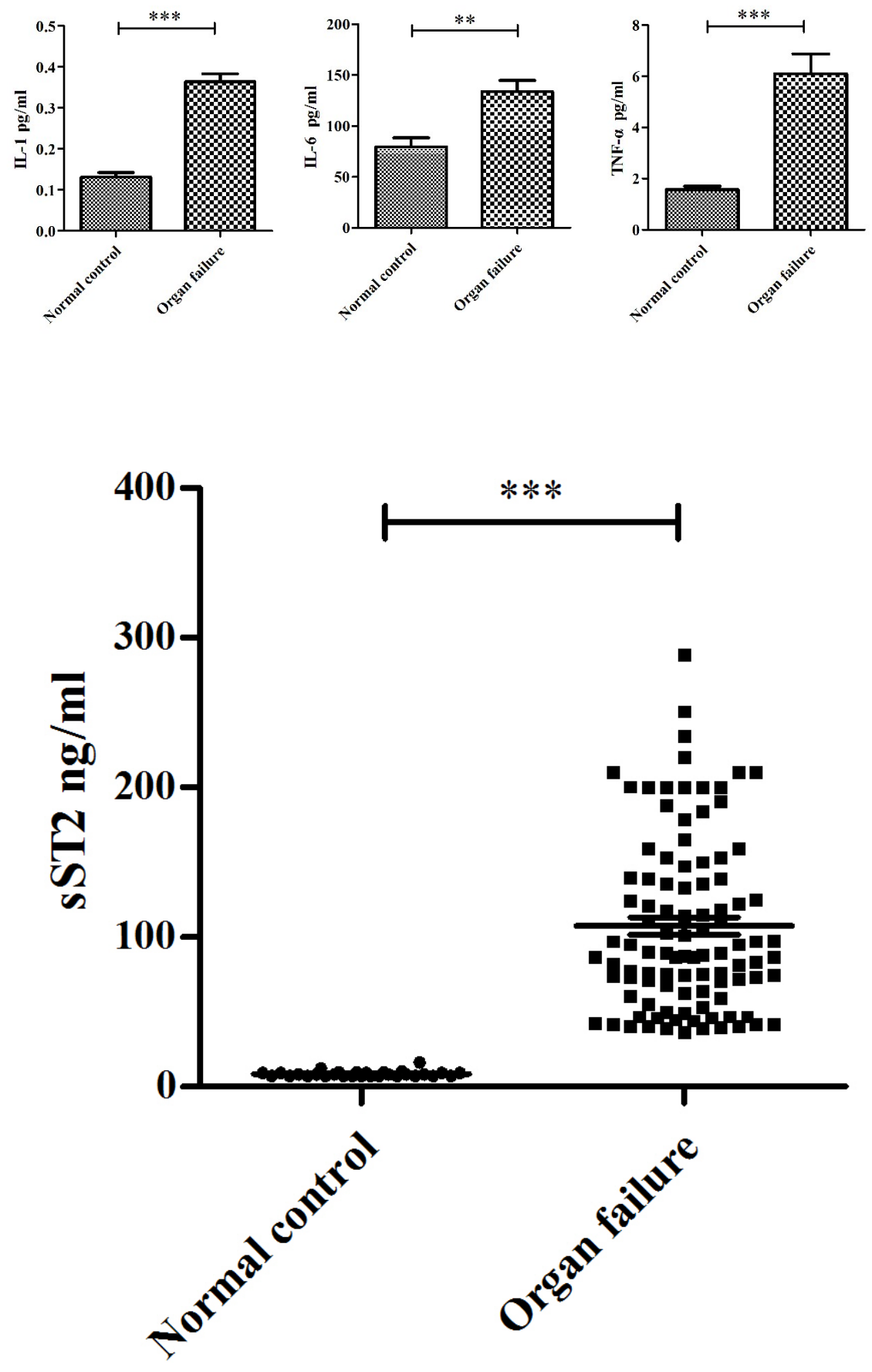
A

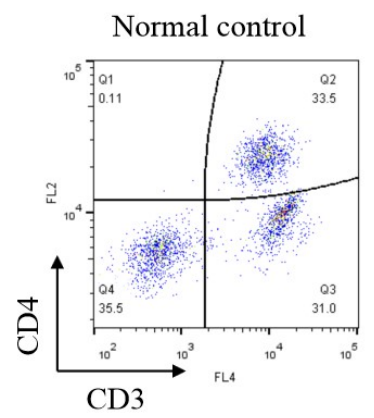

B

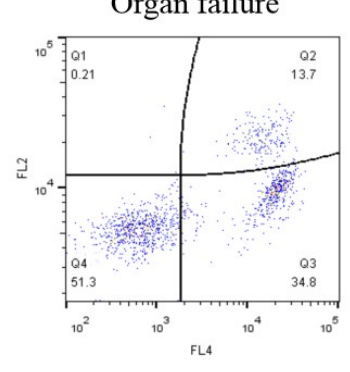

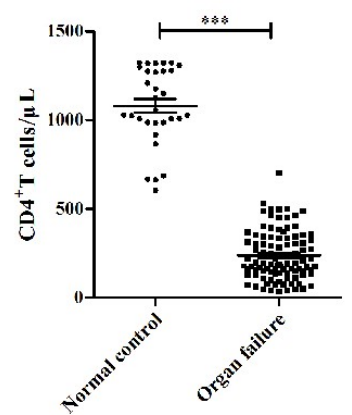

\begin{tabular}{lcc|llc}
\hline Parameters & HF & NC & Parameters & RF & NC \\
\hline Gender(M/F) & $35 / 25$ & $14 / 16$ & Gender(M/F) & $27 / 13$ & $14 / 16$ \\
Age (years) & $65.06 \pm 12.32$ & $60.23 \pm 13.99$ & Age (years) & $61.22 \pm 9.38$ & $60.23 \pm 13.99$ \\
CK-MB( $\mu \mathrm{g} / \mathrm{L})$ & $20.53 \pm 10.45^{*}$ & $0.96 \pm 0.11$ & $\mathrm{BUN}(\mathrm{mmol} / \mathrm{L})$ & $21.06 \pm 2.13^{* * *} 5.58 \pm 0.33$ \\
$\mathrm{MYO}(\mu \mathrm{g} / \mathrm{L})$ & $924.4 \pm 201.3 * * *$ & $42.41 \pm 4.94$ & $\mathrm{Cr}(\mu \mathrm{mol} / \mathrm{L})$ & $282.5 \pm 56.56^{* *}$ & $72.62 \pm 5.73$ \\
$\mathrm{cTNI}(\mu \mathrm{g} / \mathrm{L})$ & $1.123 \pm 0.35^{*}$ & $0.023 \pm 0.011$ & $\mathrm{CysC}(\mathrm{mg} / \mathrm{L})$ & $3.20 \pm 0.36^{* *}$ & $1.08 \pm 0.059$ \\
$\mathrm{BNP}(\mathrm{ng} / \mathrm{L})$ & $2753 \pm 576.1 * * *$ & $67.93 \pm 20.79$ & $\beta 2-\mathrm{MG}(\mathrm{mg} / \mathrm{L})$ & $9.74 \pm 1.48^{* * *}$ & $1.94 \pm 0.18$ \\
\hline
\end{tabular}

Correlation Coefficient

\begin{tabular}{|c|c|c|c|c|}
\hline & & & $\mathrm{CD} 4+\mathrm{T}$ & sST2 \\
\hline \multirow{6}{*}{ Spearman'rho } & \multirow{3}{*}{$\mathrm{CD} 4{ }^{+} \mathrm{T}$} & Correlation Coefficient & 1.000 & $-.458^{* *}$ \\
\hline & & Sig.(Two-tailed test) & & .000 \\
\hline & & $\mathrm{N}$ & 100 & 100 \\
\hline & \multirow{3}{*}{$\mathrm{sST} 2$} & Correlation Coefficient & $-.458^{* *}$ & 1.000 \\
\hline & & Sig.(Two-tailed test) & .000 & \\
\hline & & $\mathrm{N}$ & 100 & 100 \\
\hline
\end{tabular}

**. The correlation was significant at a confidence level of 0.01 (Two-tailed test). 